\title{
Analisis Komponen Sikap Ilmiah Siswa Dalam Buku Teks Pelajaran IPA SMP Kelas VII Pada Tema Panas Di Bumiku
}

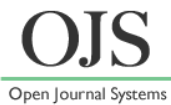

\author{
Asiani", Sjaifuddin, Lulu Tunjung Biru \\ Pendidikan IPA FKIP Universitas Sultan Ageng Tirtayasa, Banten \\ *Email: asiani1028.aa@gmail.com
}

DOI: https://doi.org/10.33369/pendipa.6.1.113-119

\begin{abstract}
The heat in my earth is a problem of the destruction of the earth due to air pollution. The heat in my earth can be used as an accurate learning resource by using textbooks to improve student's scientific attitude. The purpose of this study is to analyze the emergence of components of student's scientific attitudes in science textbooks for class VII SMP on the theme of heat in my earth. This research method was descriptive qualitative. The research instrument used was a sheet checklist. The results obtained in this study in three textbooks for science subjects SMP class VII, namely the trust component of $55.5 \%$, the feeling component of $61.0 \%$, and the action component of $62.1 \%$ with fairly good criteria. The percentage of indicators appearing to receive information, respond to information, be honest, thorough, careful, and cooperate is $66.6 \%$ with good criteria. While the indicator assesses information, curiosity, responsibility, and care for the environment, the percentage of appearance is $33.3 \%$ with bad criteria. Overall, the three student handbooks for science subjects of SMP class VII were analyzed, the belief component got the lowest percentage and the feeling component and action component got the highest percentage. While the indicators of receiving information, responding to information, being honest, thorough, careful, and cooperative get the highest percentage and indicators of assessing information, curiosity, responsibility, and caring for the environment get the lowest percentage.
\end{abstract}

Keywords: Components of Student Scientific Attitude, Science Textbooks for Class VII Junior High Schools, Heat In My Earth.

\begin{abstract}
ABSTRAK
Panas di bumiku merupakan suatu permasalahan rusaknya bumi akibat pencemaran udara. Panas di bumiku dapat dijadikan sebagai sumber belajar yang akurat dengan menggunakan bahan ajar buku teks pelajaran untuk meningkatkan kemampuan sikap ilmiah siswa. Tujuan dalam penelitian ini yaitu menganalisis kemunculan komponen sikap ilmiah siswa dalam buku teks pelajaran IPA SMP kelas VII pada tema panas di bumiku. Metode penelitian ini adalah kualitatif deskriptif. Instrumen penelitian yang digunakan yaitu lembar checklist. Hasil yang didapatkan dalam penelitian ini pada tiga buku teks pegangan siswa mata pelajaran IPA SMP kelas VII yaitu komponen kepercayaan sebesar 55,5\%, komponen perasaan sebesar $61,0 \%$, dan komponen tindakan sebesar $62,1 \%$ dengan kriteria cukup baik. Persentase kemunculan indikator menerima informasi, menanggapi informasi, jujur, teliti, hati-hati, dan kerja sama sebesar $66,6 \%$ dengan kriteria baik. Sedangkan indikator menilai informasi, rasa ingin tahu, bertanggung jawab, dan peduli lingkungan persentase kemunculannya sebesar 33,3\% dengan kriteria tidak baik. Secara keseluruhan ketiga buku teks pegangan siswa mata pelajaran IPA SMP kelas VII yang dianalisis, komponen kepercayaan mendapatkan persentase terendah dan komponen perasaan serta komponen tindakan mendapatkan persentase tertinggi. Sedangkan pada indikator menerima informasi, menanggapi informasi, jujur, teliti, hati-hati, dan kerja sama mendapatkan persentase tertinggi dan indikator menilai informasi, rasa ingin tahu, bertanggung jawab, dan peduli lingkungan mendapatkan persentase terendah.
\end{abstract}

Kata kunci: Komponen Sikap Ilmiah Siswa, Buku Teks Pelajaran IPA SMP Kelas VII, Panas Di Bumiku. 


\section{PENDAHULUAN}

Pembelajaran IPA adalah pembelajaran yang tidak menuntut hafalan, tetapi pembelajaran yang banyak memberikan latihan untuk menemukan sebuah konsep baru secara alamiah berdasarkan kaidah-kaidah IPA. Dalam kegiatan pembelajaran IPA siswa dituntut untuk mengetahui fenomena alam secara langsung dan memecahkan permasalahan yang ada bukan hanya melalui pengetahuan berupa fakta, konsep, atau prinsip saja, namun dengan menggunakan metode alamiah dan sikap alamiah. Adanya hal tersebut sejalan dengan penelitian yang dilakukan oleh (Juhji \& Nuangchalerm, 2020) yang mengungkapkan bahwa dalam kegiatan proses pembelajaran IPA, siswa harus diberikan pengalaman belajar secara langsung yang didasarkan pada proses keterampilan dan sikap ilmiah.

Sikap ilmiah merupakan sikap yang dimiliki oleh setiap ilmuwan atau akademisi dalam menghadapi atau menyelesaikan suatu permasalahan yang bersifat ilmiah untuk mendapatkan hasil yang baik secara alamiah. Oleh karena itu, sikap ilmiah perlu dikembangkan sejak dini, dengan harapan dapat menjadi bekal dalam menyelesaikan suatu permasalahan yang ada dalam kehidupan sehari-hari.

Untuk mengajarkan siswa dalam mengembangkan sikap ilmiah pada saat proses kegiatan pembelajaran berlangsung tentunya harus melalui proses pembiasaan yang dimana memerlukan peran guru dan media pembelajaran, yaitu Buku Teks Pelajaran (BTP) dalam kegiatan belajar untuk menyampaikan pesan dan isi pelajaran agar tujuan dari proses pembelajaran dapat tercapai secara maksimal.

Buku Teks Pelajaran (BTP) merupakan sumber utama dalam kegiatan belajar. Hal ini sejalan dengan penelitian (Fitriyah et al., 2017) mengungkapkan bahwa buku pelajaran mempunyai peran penting pada saat kegiatan pembelajaran berlangsung, salah satunya yaitu untuk menerapkan atau mengajarkan siswa dengan adanya nilai karakter salah satunya yaitu sikap ilmiah yang ada pada buku tersebut agar siswa memiliki perilaku yang baik.

Namun pada kenyataannya, pada hasil yang telah didapatkan ketika mewawancarai salah satu guru mata pelajaran IPA kelas VII di SMPN 1 Ciruas diketahui selama ini didalam pembelajaran IPA masih kurangnya penerapan sikap ilmiah siswa yang terdapat pada Buku Teks Pelajaran (BTP) sehingga kegiatan pembelajaran masih bersifat teacher centered. Berdasarkan hal tersebut sejalan dengan penelitian (Khairawati dkk., 2018) mengungkapkan pada Buku Teks Pelajaran (BTP) IPA dalam kegiatan pembelajaran di sekolah penerapan sikap ilmiah siswa yang ada disekolah masih jauh dari yang diharapkan. Dimana hal tersebut dapat terlihat bahwa masih kurangnya kegiatan pembelajaran dalam Buku Teks Pelajaran (BTP) IPA yang menuntut siswa untuk lebih mandiri dalam kegiatan pembelajaran agar menemukan sebuah konsep baru pada saat kegiatan pemecahan masalah.

Dengan adanya permasalahan tersebut, maka perlu dibuat sebuah solusi pemecahan masalah yaitu berupa cara menganalisis komponen sikap ilmiah siswa yang terdapat didalam buku teks pelajaran IPA. Dimana penyajian yang ada didalam buku mata pelajaran IPA ini dapat dicocokkan dengan sikap ilmiah yang dapat membantu mengembangkan isi dari sikap ilmiah siswa.

Sependapat dengan adanya hal tersebut, berdasarkan penelitian (Nugroho et al., 2017) mengungkapkan perlu dilakukannya sebuah kegiatan menganalisis materi yang ada pada buku ajar IPA untuk mengetahui kekurangan dan kelebihan pada buku teks pelajaran tersebut serta untuk mengetahui tingkat kesesuaian atau kerelevanan materi dalam kehidupan sehari-hari.

Materi yang dipilih untuk menganalisis komponen sikap ilmiah siswa yang dimana ada didalam buku mata pelajaran IPA SMP kelas VII ini termuat pada sebuah tema panas di bumiku. Tema panas di bumiku ini merupakan sebuah tema dalam kegiatan pembelajaran yang terdiri dari beberapa konsep untuk diajarkan di SMP. Isi materi yang ada didalam tema panas di bumiku merupakan sebuah materi yang kompleks didalamnya. Jadi selain diperlukan proses berpikir yang lebih dari sekedar menghafal, diperlukan juga melakukan sebuah pembuktian secara ilmiah berdasarkan permasalahan yang ada untuk menemukan sebuah konsep baru. Pemilihan tema ini berdasarkan pada kegiatan PPLK dimana telah diketahui bahwa masih kurangnya kepedulian terhadap lingkungan sekitar sehingga merekapun merasakan dampaknya akibat tidak pedulinya terhadap lingkungan sekitar.

Berdasarkan paparan latar belakang penelitian yang telah ada, maka rumusan 
masalah yang ada didalam penelitian ini yaitu bagaimana kemunculan komponen sikap ilmiah siswa dalam buku teks pelajaran IPA SMP Kelas VII pada tema panas di bumiku ? dan tujuan pada penelitian ini yaitu untuk menganalisis kemunculan komponen sikap ilmiah siswa dalam buku teks pelajaran IPA SMP kelas VII pada tema panas di bumiku.

\section{METODE PENELITIAN}

Metode yang digunakan didalam kegiatan penelitian ini yaitu pendekatan kualitatif yang bersifat deskriptif. Metode yang digunakan didalam penelitian deskriptif ini yaitu untuk mendeskripsikan, mencatat, menganalisis, serta menginterpretasikan keadaan yang ada didalam sebuah bahasa verbal mengenai komponen sikap ilmiah dalam buku teks yang menjadi pegangan siswa pada mata pelajaran IPA SMP kelas VII. Adanya hal tersebut sependapat dengan penelitian (Gumilang, 2016) mengungkapkan penelitian kualitatif ini bukan berbentuk angka, namun berbentuk deskripsi, alur cerita, serta dokumentasi tersurat dan tersirat. Dengan adanya hal tersebut dapat diketahui bahwa sebuah data yang telah dianalisis tidak diperuntukkan agar dapat menerima atau menolak sebuah hipotesis, namun dapat berupa deskripsi berdasarkan fenomena yang diamati. Desain yang digunakan didalam kegiatan penelitian ini yaitu dengan cara menganalisis buku teks yang menjadi pegangan siswa dalam pelajaran IPA SMP kelas VII kemudian mencocokkannya dengan komponen sikap ilmiah siswa yang ada untuk di analisis.

Subjek yang dipergunakan dalam kegiatan penelitian ini berupa buku teks yang menajdi pegangan siswa pada pelajaran IPA SMP kelas VII yang dimana menggunakan 3 buku diantaranya yaitu buku kemendikbud edisi revisi 2017, buku erlangga, dan buku yudhistira. Waktu yang digunakan dalam kegiatan penelitian ini yaitu dilakukan pada semester ganjil tahun ajaran 2020/2021 pada bulan Desember 2020 hingga Januari 2021.

Teknik dalam kegiatan pengumpulan sebuah data yang akan digunakan pada kegiatan penelitian ini yaitu menggunakan sebuah metode dokumentasi. Dokumentasi digunakan untuk dapat memperoleh data dengan cara menganalisis sebuah media tertulis yaitu buku teks pelajaran. Dengan adanya hal tersebut sejalan dengan penelitian (Aprianti dkk., 2015) diketahui cara dokumentasi adalah sebuah cara pengumpulan data kualitatif dengan teknik melihat atau teknik menganalisis sebuah media tertulis dan sebuah dokumen lainnya yang bersifat tertulis ataupun dibuat secara langsung oleh subjek yang ada.

Dalam penelitian ini menggunakan instrumen berupa sebuah lembar untuk menganalisis yaitu berupa lembar checklist untuk memperoleh sebuah data komponen sikap ilmiah siswa yang ada didalam buku teks pegangan siswa dalam pelajaran IPA SMP kelas VII pada tema panas di bumiku dan lembar angket validasi intrumen digunakan untuk mengetahui kelayakan pada sebuah instrumen penelitian.

Analisis data yang akan digunakan dalam kegiatan penelitian ini yaitu berbentuk sebuah analisis deskriptif, dimana cara tersebut yang akan digunakan dalam menganalisis data penelitian ini yaitu dengan cara memaparkan kemunculan komponen sikap ilmiah siswa yang terdapat didalam buku teks yang menjadi pegangan siswa dalam pelajaran IPA SMP kelas VII pada tema panas di bumiku. Hasil analisis data ini berupa kemunculan komponen sikap ilmiah siswa pada setiap subjek yang diamati dengan memperhatikan karakteristik data yang diperoleh.

Cara menghitung dan menganalisis persentase kemunculan setiap komponen sikap ilmiah siswa didalam buku teks pegangan siswa pada pelajaran IPA SMP kelas VII pada tema panas di bumiku dengan sumber buku yang berbeda-beda yaitu buku kemendikbud edisi revisi 2017, buku erlangga, dan buku yudhistira maka rumus yang digunakan dalam menganalisis ketiga buku tersebut yaitu:

$$
\% \mathrm{P}=\frac{F}{N} \times 100 \%
$$

(Risma dkk., 2019)

Kemudian data yang diperoleh diberikan penilaian berdasarkan dengan kriteria pada tabel 1 .

Tabel 1. Kelayakan buku teks pelajaran IPA SMP kelas VII berdasarkan komponen sikap ilmiah siswa (Riduwan, 2010)

\begin{tabular}{cc}
\hline Presentase & Kriteria \\
\hline $85 \%-100 \%$ & Sangat Baik \\
$65 \%-84 \%$ & Baik \\
$55 \%-64 \%$ & Cukup Baik \\
$40 \%-54 \%$ & Kurang Baik \\
$0 \%-39 \%$ & Tidak Baik \\
\hline
\end{tabular}




\section{HASIL DAN PEMBAHASAN}

Buku yang telah dilakukan sebuah analisis didalam penelitian ini sebanyak tiga buku dengan penerbit berbeda diantaranya yaitu buku kemendikbud edisi revisi 2017, buku erlangga, dan buku yudhistira dimana ketiga buku tersebut akan kita sebut sebagai buku A, buku B, dan buku C. Dalam kegiatan menganalisis buku ini dilakukan oleh lima efektor / pengamat yaitu tiga orang guru IPA SMPN 1 Ciruas dan 2 orang validator ahli.

\section{Ruang Lingkup Kemunculan Komponen Sikap Ilmiah Siswa Pada Buku Teks Yang Dianalisis}

Dalam gambar 1 pada buku A yaitu buku kemendikbud edisi revisi 2017 dapat dilihat bahwa persentase kemunculan komponen sikap ilmiah siswa berdasarakan tema panas di bumiku memiliki persentase lebih tinggi yaitu sebesar 63,3\% dengan kriteria cukup baik dari buku B yaitu buku erlangga yang memiliki persentase sebesar $60 \%$ dengan kriteria cukup baik. Sedangkan untuk buku C yaitu buku yudhistira memiliki persentase kemunculan komponen sikap ilmiah siswa berdasarkan tema panas di bumiku memiliki persentase terendah yaitu sebesar 56,6\% dengan kriteria cukup baik. Ketiga buku tersebut sudah layak digunakan jika dilihat dari segi komponen sikap ilmiah siswa.

Tabel 2. Perbandingan tiga buku IPA SMP kelas VII berdasarkan komponen sikap ilmiah siswa pada tema panas di bumiku

\begin{tabular}{cccc}
\hline & \multicolumn{3}{c}{ Persentase Dan Kriteria Komponen } \\
Sudul & \multicolumn{3}{c}{ Sikap Ilmiah Siswa } \\
\cline { 2 - 4 } Buku & Komponen & Kompone & Kompone \\
& Kepercayaa & n & n \\
& $\mathrm{n}$ & Perasaan & Tindakan \\
Buku & $55,5 \%$ & $66,6 \%$ & $66,6 \%$ \\
$\mathrm{~A}$ & $($ Cukup & $($ Baik $)$ & $($ Baik $)$ \\
& Baik) & $50 \%$ & \\
Buku & $55,5 \%$ & $66,6 \%$ \\
B & (Cukup & $($ Kurang & $($ Baik) \\
& Baik) & Baik) & \\
Buku & $55,5 \%$ & $66,6 \%$ & $53,3 \%$ \\
C & $($ Cukup & $($ Baik $)$ & (Kurang \\
& Baik) & Baik) \\
\hline
\end{tabular}

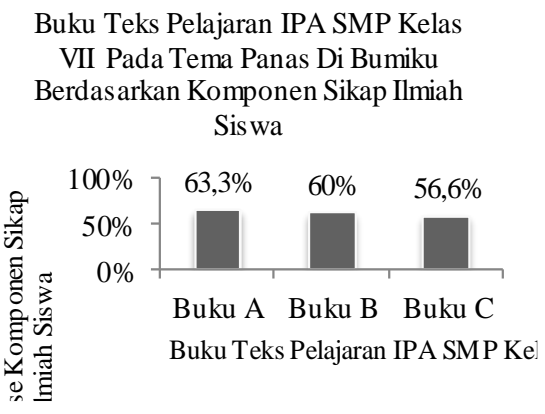

G

ambar 1. Hasil analisis buku IPA SMP kelas VII pada tema panas di bumiku

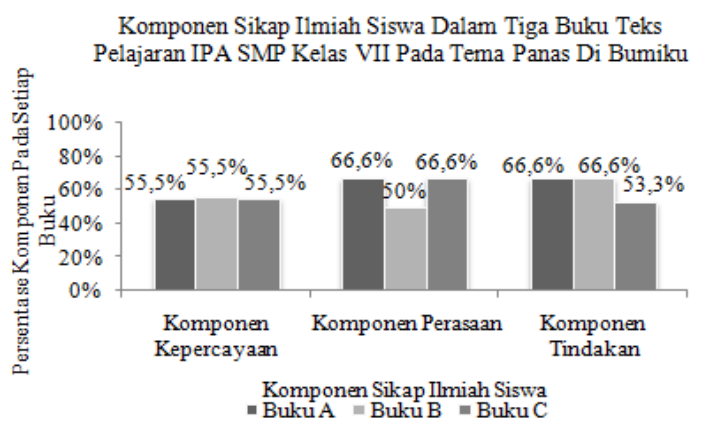

Gambar 2. Komponen sikap ilmiah siswa dalam tiga buku IPA tema panas di bumiku

Adaya perbedaan persentase dari ketiga buku teks pelajaran yang dianalisis tersebut dapat dikatakan bahwa semakin tinggi persentase komponen sikap ilmiah siswa yang ada pada buku teks pelajaran maka akan semakin mudah dalam mengembangkan kemampuan komponen sikap ilmiah siswa. Dengan adanya keberadaan hal tersebut sejalan dengan penelitian (Cahyono dkk., 2018) mengungkapkan kegiatan pembelajaran dengan menggunakan sebuah buku teks pelajaran yang dimana didalamnya terdapat suatu pendidikan karakter akan dengan mudah meningkatkan pendidikan karakter pada peserta didik.

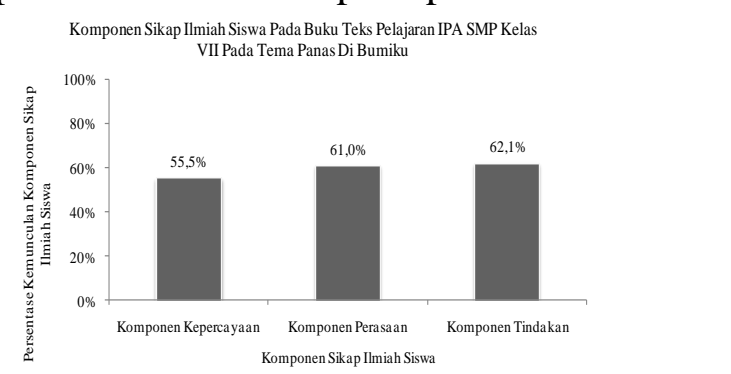

Gambar 3. Kemunculan komponen sikap ilmiah siswa 
Pada gambar 3 dapat dilihat bahwa komponen sikap ilmiah siswa pada komponen tindakan sangat mendominasi atau memiliki persentase yang sangat tinggi dari pada dua komponen lainnya dimana pada komponen tindakan memiliki persentase sebesar $62,1 \%$, komponen perasaan memiliki persentase sebesar $61,0 \%$, dan komponen kepercayaan memiliki persentase sebesar 55,5\%.

\section{Ruang Lingkup Pada Masing-Masing Komponen Sikap Ilmiah Siswa Pada Buku Teks Yang Dianalisis}

Analisis ruang lingkup pada komponen sikap ilmiah siswa ini bertujuan untuk mengetahui proposi kemunculan indikator pada masing-masing komponen sikap ilmiah siswa dalam buku A yaitu buku kemendikbud edisi revisi 2017, buku B yaitu buku erlangga, dan buku $\mathrm{C}$ yaitu buku yudhistira.

\section{Komponen Kepercayaan}

Data yang diperoleh sejalan dengan penelitian (Rahmawati, 2015) mengungkapkan sebuah informasi yang telah disajikan dalam sebuah buku teks pelajaran akan turut menilai apakah informasi yang terdapat didalam buku teks pelajaran tersebut sudah terbukti kebenarannya dan dapat dijadikan sebuah sumber informasi yang tepat untuk dapat memenuhi sebuah kebutuhan informasi didalam buku teks pelajaran yang digunakan

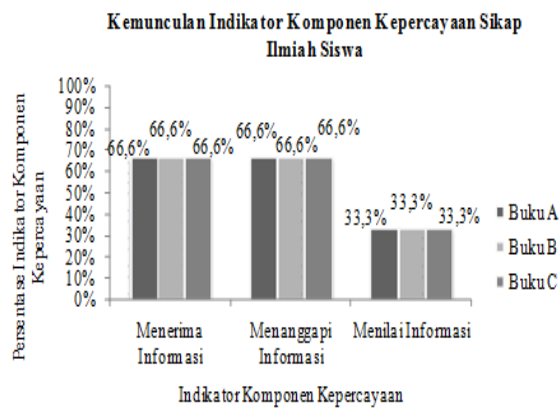

Gambar 4. Kemunculan indikator komponen kepercayaan sikap ilmiah siswa

Tabel 3. Hasil dari ketiga indikator pada komonen kepercayaan dalam ketiga buku IPA SMP kelas VII berdasarkan komponen sikap ilmiah siswa pada tema panas di bumiku

\begin{tabular}{cc}
\hline & Persentase Dan Kriteria \\
Indikator & Indikator Komponen \\
Komponen & Kepercayaan Sikap Ilmiah \\
Kepercayaan & Siswa Dalam Tiga Buku \\
& Teks Pelajaran IPA SMP \\
\hline
\end{tabular}

\begin{tabular}{cccc}
\hline & \multicolumn{3}{c}{ Kelas VII } \\
\cline { 2 - 4 } & Buku A & Buku & Buku \\
Menerima & $66,6 \%$ & $66,6 \%$ & $66,6 \%$ \\
Informasi & $($ Baik) & (Baik) & (Baik) \\
Menanggapi & $66,6 \%$ & $66,6 \%$ & $66,6 \%$ \\
Informasi & (Baik) & (Baik) & (Baik) \\
Menilai & $33,3 \%$ & $33,3 \%$ & $33,3 \%$ \\
Informasi & (Tidak & (Tidak & (Tidak \\
& Baik) & Baik) & Baik) \\
\hline
\end{tabular}

\section{Komponen Perasaan}

Komponen perasaan ini sangat mempengaruhi seseorang untuk mencari tahu secara kompleks terhadap sesuatu yang telah dipelajari, dilihat, dan didengar sehingga tujuan dari kegiatan pembelajaran akan berhasil dan tercapai. Adanya hal tersebut sejalan dengan penelitian (Novelyya, 2019) mengungkapkan adanya karakter atau sikap yang dimiliki oleh seseorang sangat berpengaruh dalam keberhasilan dan pencapaian tujuan pembelajaran dimana karakter tersebut adalah rasa ingin tahu dan jujur. Dengan adanya dua karakter tersebut dapat mendorong siswa menjadi aktif pada saat kegiatan pembelajaran berlangsung dan menjadikan siswa untuk mengetahui lebih mendalam atas apa yang dipelajarinya.

Tabel 4. Indikator pada komponen perasaan dalam ketiga buku IPA SMP kelas VII berdasarkan komponen sikap ilmiah siswa pada tema panas di bumiku

\begin{tabular}{|c|c|c|c|}
\hline \multirow[t]{2}{*}{$\begin{array}{l}\text { Indikator } \\
\text { Komponen } \\
\text { Perasaan }\end{array}$} & \multicolumn{3}{|c|}{$\begin{array}{c}\text { Persentase Kriteria Indikator } \\
\text { Komponen Perasaan Sikap } \\
\text { Ilmiah Siswa Dalam Tiga } \\
\text { Buku Teks Pelajaran IPA } \\
\text { SMP Kelas VII } \\
\end{array}$} \\
\hline & Buku A & Buku B & $\begin{array}{c}\text { Buku } \\
\mathrm{C}\end{array}$ \\
\hline $\begin{array}{c}\text { Rasa Ingin } \\
\text { Tahu }\end{array}$ & $\begin{array}{l}66,6 \% \\
\text { (Baik) }\end{array}$ & $\begin{array}{c}33,3 \% \\
\text { (Tidak } \\
\text { Baik) }\end{array}$ & $\begin{array}{l}66,6 \% \\
\text { (Baik) }\end{array}$ \\
\hline Jujur & $\begin{array}{l}66,6 \% \\
\text { (Baik) }\end{array}$ & $\begin{array}{l}66,6 \% \\
\text { (Baik) }\end{array}$ & $\begin{array}{l}66,6 \% \\
\text { (Baik) }\end{array}$ \\
\hline
\end{tabular}




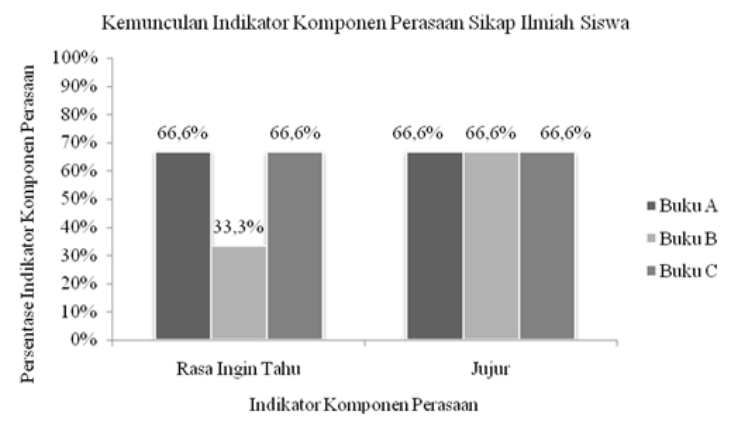

Gambar 5. Kemunculan indikator komponen perasaan sikap ilmiah siswa

\section{Komponen Tindakan}

Kemunculan komponen tindakan ini sangat mempengaruhi seseorang dalam melakukan pembelajaran secara mandiri dalam memecahkan suatu permasalahan yang ada untuk menemukan sebuah konsep baru. Dengan adanya hal tersebut sejalan dengan penelitian (Astalini dkk., 2020) mengungkapkan bahwa komponen tindakan tidak kalah penting dalam pembelajaran IPA dimana siswa harus dapat melangsungkan kegiatan pembelajaran secara mandiri melalui sebuah penyelidikan pada konsep IPA secara langsung untuk menemukan sebuah konsep baru.

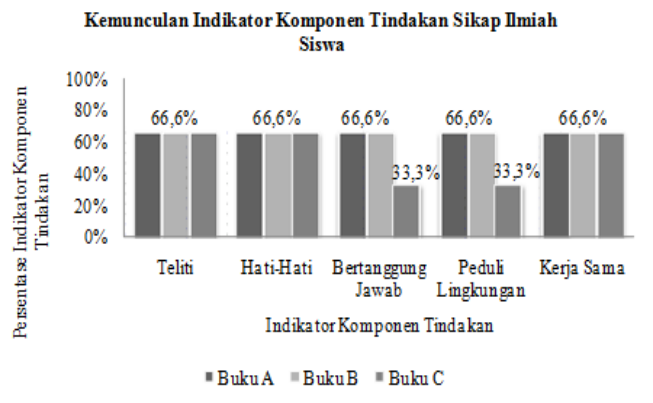

Gambar 6. Kemunculan indikator komponen tindakan sikap ilmiah siswa

Tabel 5. Hasil dari kelima indikator pada komonen tindakan dalam ketiga buku IPA SMP kelas VII berdasarkan komponen sikap ilmiah siswa pada tema panas di bumiku Persentase Kriteria Indikator Indikator Komponen Tindakan Sikap Komponen Ilmiah Siswa Dalam Tiga Tindakan Buku Teks Pelajaran IPA SMP Kelas VII

\begin{tabular}{cccc}
\hline & Buku A & Buku B & $\begin{array}{c}\text { Buku } \\
\text { C }\end{array}$ \\
Teliti & $66,6 \%$ & $66,6 \%$ & $66,6 \%$ \\
& $($ Baik) & $($ Baik) & (Baik) \\
Hati-Hati & $66,6 \%$ & $66,6 \%$ & $66,6 \%$ \\
& $($ Baik) & $($ Baik) & $($ Baik) \\
Kerja Sama & $66,6 \%$ & $66,6 \%$ & $66,6 \%$ \\
& $($ Baik) & $($ Baik) & $($ Baik) \\
Bertaggung & $66,6 \%$ & $66,6 \%$ & $33,3 \%$ \\
Jawab & $($ Baik) & $($ Baik) & (Tidak \\
& & & Baik) \\
Peduli & $66,6 \%$ & $66,6 \%$ & $33,3 \%$ \\
Lingkungan & $($ Baik) & $($ Baik) & (Tidak \\
& & & Baik) \\
\hline
\end{tabular}

\section{KESIMPULAN}

Dengan adanya hasil penelitian yang sudah didapatkan dalam tiga buku pelajaran IPA SMP kelas VII pada tema panas di bumiku berdasarkan pada komponen sikap ilmiah siswa, dapat diberikan kesimpulan bahwa ketiga buku pelajaran IPA SMP kelas VII tersebut sudah menerapkan tiga komponen sikap ilmiah siswa. Dimana kemunculan komponen sikap ilmiah siswa dalam tiga buku pelajaran IPA SMP kelas VII tersebut yaitu Persentase komponen kepercayaan sebesar $55,5 \%$, persentase komponen perasaan sebesar $61,0 \%$, dan persentase komponen tindakan sebesar $62,1 \%$, dimana ketiga komponen sikap ilmiah tersebut memiliki kriteria cukup baik. Kemudian dapat disimpulkan bahwa persentase kemunculan indikator komponen sikap ilmiah siswa pada indikator menerima informasi, menanggapi informasi, jujur, teliti, hati-hati, dan kerja sama memiliki persentase lebih tinggi yaitu sebesar $66,6 \%$ dengan kriteria baik. Sedangkan persentase kemunculan indikator komponen sikap ilmiah siswa pada indikator menilai informasi, rasa ingin tahu, bertanggung jawab, dan peduli lingkungan memiliki persentase terendah yaitu sebesar 33,3\% dengan kriteria tidak baik. Oleh karena itu, perlu adanya perhatian agar komponen sikap ilmiah siswa beserta indikator didalamnya lebih dimasukkan secara seimbang pada buku pelajaran IPA SMP kelas VII agar dapat memberikan gambaran sikap ilmiah secara utuh kepada siswa.

\section{DAFTAR PUSTAKA}

Aprianti, W., Gunatama, G., \& Indriani, M. S. (2015). Analisis Fakta dan Sarana Cerita dalam Teks Nilai Moral Fabel Siswa Kelas VIII A1 di SMP Negeri 1 Singaraja. 
E-Journal Jurusan Pendidikan Bahasa Dan Sastra Indonesial, 3(1), 1-11.

Astalini, A., Kurniawan, D. A., Darmaji, D., \& Kurniawan, N. (2020). Analisis Sikap Siswa Terhadap Ipa Di Smp Kabupaten Muaro Jambi. Jurnal Pendidikan Sains (Jps), 8(1), 18.

Cahyono, B., Tsani, D., \& Rahma, A. (2018). Pengembangan Bahan Ajar Buku Saku Matematika Berbasis Pendidikan Karakter Materi Trigonometri. Phenomenon: Jurnal Pendidikan MIPA, 8(2), 185-199.

Fitriyah, M., Made D.P, N., \& Yulianto, A. (2017). Content analysis of value of character: a case study of physics textbook in rembang regency. Unnes Science Education Journal, 6(3), 1700-1707.

Gumilang, G. S. (2016). Metode Penelitian Kualitatif Dalam Bidang Bimbingan Dan Konseling. Kediri: Jurnal Fokus Konseling. Vol. 2. No. 2. Hal. 144-159.

Juhji, J., \& Nuangchalerm, P. (2020). Interaction between scientific attitudes and science process skills toward technological pedagogical content knowledge. Journal for the Education of Gifted Young Scientists, 8(1), 1-16.

Khairawati., Rahayu, H. M., dan Setiadi, A. E. (2018). Analisis Korelasi Sikap Ilmiah Dan Prestasi Belajar Siswa Di SMPN 3 Sungai Kakap. Pontianak, Kalimantan Barat: Pena Kreatif: Jurnal Pendidikan. Vol. 7. No. 1. Hal. 52-61.
Novelyya, S. (2019). Pengaruh Karakter Rasa Ingin Tahu Siswa Terhadap Hasil Belajar Mata Pelajaran Ipa Fisika Di Smp Negeri 08 Muaro Jambi. Briliant: Jurnal Riset Dan Konseptual, 4(2), 174.

Nugroho, E. D., Vlorensius, V., Rasidah H., L., \& Anisa, N. (2017). The Content Analysis, Material Presentation, and Readability of Curriculum 2013 Science Textbook for 1st Semester of Junior High School 7th Grade. Jurnal Pendidikan Biologi Indonesia, 3(2), 114.

Rahmawati, G. (2015). Buku Teks Pelajaran sebagai Sumber Belajar Siswa di Perpustakaan Sekolah di SMAN 3 Bandung. EduLib, 5(1), 102-113.

Riduwan. (2015). Belajar Mudah Penelitian Untuk Guru, Karyawan dan Penulis. Bandung: Alfabeta.

Risma, M., Rahmayani, R., \& Handayani, F. (2019). Analisis Konten Buku Teks IPA Terpadu Kelas VIII Semester 1 Ditinjau Dari Aspek Literasi Saintifik. Jurnal Eksakta Pendidikan (Jep), 3(2), 200. 